\title{
Zbigniew Czarnik
}

WSPiA University of Rzeszow, Poland

Supreme Administrative Court, Poland

ORCID: 0000-0001-8459-1108

zczarnik@wspia.eu

\section{The Legitimacy of Preliminary Questions to the Court of Justice of the European Union (CJEU) on the Legal Status of Supreme Court Judges in Poland}

\author{
Zasadność pytań prejudycjalnych do Trybunału Sprawiedliwości \\ Unii Europejskiej (TSUE) w sprawach statusu prawnego sędziów \\ Sądu Najwyższego w Polsce
}

\section{ABSTRACT}

The analysis presented in this article concerns the impact of Court of Justice of the European Union (CJEU) jurisprudence on the legal situation of Supreme Court and Supreme Administrative Court judges in Poland. The main assumption of the presented considerations is that the CJEU, in providing answers to preliminary questions submitted to it by Polish courts adjudicating cases related to judicial appointments and retirements, strengthens the independence of the courts and the independence of the judiciary, assuming that these are systemic elements of a functioning judiciary subject to EU law. For this reason, the CJEU considers itself competent to shape these systemic values under Polish law. At the same time, this body does not notice the problem of jurisdiction of Polish courts posing legal questions, which becomes an important theoretical and practical issue, because it may affect the legality and effectiveness of judgements passed on the basis of answers given by the CJEU. Detailed considerations focus on two types of judgements of the CJEU, which were made in connection with the retirement of judges, as a result of questions submitted to the Court by the Supreme Court and Supreme Administrative Court. The subject of the questions related to the compatibility with EU law of the scope of legal protection granted in Polish law to a judge against resolutions adopted in such cases by the National Council of the Judiciary. The considerations presented conclude that in the case of a CJEU judgement issued as a result of a question posed by the Supreme Court, the

CORRESPONDENCE ADDRESS: Zbigniew Czarnik, PhD, Dr. Habil., Professor of the University, Judge of the Supreme Administrative Court, WSPiA University of Rzeszow, Cegielniana 14, 35-310 Rzeszow, Poland. 
jurisdiction of the authority posing the question was infringed, and this should have consequences for the scope of binding the court adjudicating on the answer provided by the CJEU.

Keywords: preliminary questions; Court of Justice of the European Union; National Council of the Judiciary; National Council of the Judiciary; retirement of judges; Polish law

\section{INTRODUCTION}

The aim of the considerations undertaken in this article is to present a legal problem that has arisen in connection with changes made in Poland in the broadly understood judiciary reforms. In this context, divergences appeared concerning the possibility of the retirement of judges, especially the compatibility of legal solutions proposed by the Polish legislator with EU law. As a result, the Court of Justice of the European Union (CJEU) took action, and after the Supreme Court and the Supreme Administrative Court submitted relevant questions, the CJEU evaluated the normative solutions adopted in Poland concerning the rules of retiring judges ${ }^{1}$ of the Supreme Court and the Supreme Administrative Court, and also expressed its opinion on the control of acts - resolutions of the National Council of the Judiciary adopted in the procedure for appointing judges ${ }^{2}$ and upon the retirement of judges. In both cases, despite the different subject matter to which the questions referred for a preliminary ruling relate, a common legal problem arises. It relates to the competence of the CJEU to make a statement in this area, and thus the ability of the competent national courts to answer the questions posed, when considering legal remedies against resolutions adopted by the bodies mentioned above ruling on specific cases.

This common denominator, which appears in the case of questions referred to the CJEU for a preliminary ruling, allows for a general treatment of the issue under consideration, despite the substantive differences of the CJEU rulings themselves. In each of them, the question of whether the CJEU was the competent court to answer the questions posed by the Supreme Court and Supreme Administrative Court comes to the foreground. In the doubt that arises in this respect, it is not a question of whether under Article 267 of the Treaty on the Functioning of the European Union $^{3}$ the Tribunal is competent to hear a question for a preliminary ruling, since the fact that it may act within this scope is undisputed. It may be controversial in this respect that the CJEU assumed its jurisdiction to answer questions, without explicit reference to the jurisdiction of the national courts submitting the question and the subject matter of the case that gave rise to the answer. Deficiencies in this

1 For example, see judgement of the CJEU of 19 November 2019, C-585/19, C-624/18 and C-625/18, ECLI:EU:C:2019:982.

2 Judgement of the CJEU of 2 March 2021, C-842/18.

3 Journal of Laws 2004, no. 90, item 864/2, hereinafter: TFEU. 
respect may be a cause for concern, because they give rise to the conclusion that in the case of questions for a preliminary ruling, the CJEU does not examine its subject-matter jurisdiction and the formal correctness of the request. This concern is all the more justified in light of the fact that none of the rulings subject to analysis, issued under the preliminary ruling procedure, i.e. relating to the retirement status of Supreme Court judges and review of National Council of the Judiciary resolutions on the nomination of candidates for the position of judge in the Supreme Court, mentioned this issue. Thus, it is reasonable to assume that the CJEU responds to a question for a preliminary ruling without examining whether it comes from the competent court from the point of view of national law, on the assumption that the court asking the question always acts within its competence, and the CJEU has no power to interpret national law. It therefore examines its jurisdiction and the admissibility of the question from the point of view of the EU law. ${ }^{4}$

The verification of such an assumption shall be made within the framework of a dogmatic analysis, i.e. the presentation of normative grounds related to the status of judges of the Supreme Court and Supreme Administrative Court and the legal consequences resulting from the answers given by the CJEU to the Polish courts within the framework of preliminary issues within the meaning of Article 267 TFEU. Within the scope of national regulations, the basic tool implementing the dogmatic approach to the presented problems is the linguistic and logical method as well as the analytical method, while in the conducted considerations both of them intermingle due to the impossibility of their clear separation on the grounds of the interpretation of normative material. ${ }^{5}$ On the other hand, in the references to the EU law, and especially CJEU jurisprudence, argumentative elements occur.

\section{THE PROCEDURAL ASPECT OF PRELIMINARY QUESTIONS SHAPING THE SYSTEMIC POSITION OF SUPREME COURT JUDGES}

\section{General comments}

In the background of the dispute related to the reform of the Polish judiciary in 2017-2019, legal problems, including those of a systemic nature, hitherto unnoticed or even non-existent, have emerged. First of all, it was necessary to raise the question of the relationship between the courts in Poland and the EU law, assuming, naturally, that the Polish courts are, at the same time, the European Union courts,

4 See A. Sikora, Praktyka Trybunału Sprawiedliwości w postępowaniach na podstawie art. 267 TFUE w świetle orzecznictwa i ostatniej reformy procedury, "Europejski Przegląd Sądowy" 2014, no. 11, pp. 35-41.

5 See J. Stelmach, B. Brożek, Metody prawnicze, Kraków 2004, pp. 37-39. 
and thus to answer the question to what extent EU law shapes the systemic model of national judiciary, including influencing the status of judges in general, and judges of the Supreme Court and the Supreme Administrative Court in particular, as judges of courts of last instance within the meaning of EU regulations. Attempts made at that time, by various entities, to change the current legal status regulating the legal status of judges and actions aimed at stopping such changes became the subject of statements of many EU bodies, but above all they resulted in CJEU rulings. It was basically the result of preliminary questions submitted to the CJEU by the formations of the Supreme Court and Supreme Administrative Court adjudicating on cases involving appointment to judicial office or retirement of a judge. In each of those cases, without going into the merits of the case, the rulings issued by the CJEU were the basis for the rulings passed by the Polish courts. The analysis of their content and the arguments presented in support of their accuracy lead to the conclusion that certain aspects related to the issue of questions for a preliminary ruling to the CJEU have not been noticed, although they seem fundamental for the correct application of the law.

First of all, a doubt arises as to whether in the case of the CJEU ruling on retirement of judges of the Supreme Court and Supreme Administrative Court, particularly under Article $111 \S 1$ of the Act of 8 December 2017 on the Supreme Court, ${ }^{6}$ the question for a preliminary ruling was referred by the competent national court, and whether in such a situation the CJEU could answer the question. It depends on the resolution of this issue to assess the further consequences that followed the CJEU judgement of 19 November $2019,{ }^{7}$ in particular the judgement of the Supreme Court of 5 December $2019^{8}$ implementing the guidelines addressed by the CJEU to the court making the preliminary question, and consequently for the resolution of the Supreme Court of 23 January 2020. ${ }^{9}$ The ambiguities appearing in this respect require an in-depth analysis as they affect the stability of the Polish legal order. Therefore, further considerations will focus primarily on this issue, although each of the presented judgements has many very interesting threads in the field of substantive and procedural law. Some of the theses contained in them may be considered accurate, while others are completely misguided. However, due to the limited size of the article and its different scope, they cannot be the subject of in-depth consideration. If they appear, it is only on the margins of the main argument, more to illustrate the essence of the raised issue, and not as independent problems. Besides, it should be assumed that every problem of jurisprudence con-

\footnotetext{
6 Journal of Laws 2018, item 5, hereinafter: the Supreme Court Act.

7 Judgement of the CJEU of 19 November 2019, C-585/19, C-624/18 and C-625/18, ECLI:EU:C:2019:982.

8 III PO 7/18, BOSN.

9 BSA I 4110-1/20, LEX no. 2770251.
} 
sists of basic and supplementary questions. The fundamental ones determine the meaningfulness of the latter. In the present case, the jurisdiction of the courts, i.e. that of the court asking the question for a preliminary ruling and that of the court subsequently deciding the case, must be regarded as fundamental, which further justifies limiting the scope of the considerations.

The considerations undertaken here focus on the legal status of a Supreme Court judge, which in practice means that they also apply to judges of the Supreme Administrative Court, since this group of judges does not have separate regulations concerning retirement status. In this respect, the regulations applicable to Supreme Court judges apply directly to Supreme Administrative Court judges. Indirectly, however, the presented comments may be used as a basis for evaluating the acquisition of retirement status by common and administrative court judges, but not so much in terms of the conditions for retirement status as such, as they may have their specificity depending on the status of the judge, although under the current law there are no such differences. As far as common and administrative court judges are concerned, it should always be borne in mind that the provisions concerning common court judges apply ${ }^{10}$ mutatis mutandis to administrative (voivodship) court judges. Regardless of the above, the purpose of the views presented here is not to analyse the differences arising in the substantive conditions for retirement, but to indicate the procedural consequences of CJEU judgements resolving preliminary questions arising in connection with retirement.

\section{Competence of the body making a reference for a preliminary ruling under Article 267 TFEU}

An analysis of the provisions governing proceedings before the CJEU concerning questions referred for a preliminary ruling leads to the conclusion that there are no clear rules in this regulation which indicate that the jurisdiction of the authority making the reference for a preliminary ruling must be examined. It follows from the wording of Article $100 \S 1$ of the Rules of Procedure of the Court of Justice of 25 September $2012^{11}$ that the Court, as a rule, has jurisdiction to hear and determine a question referred for a preliminary ruling unless the court raising the question withdraws its motion, which it may do until providing the date on which the judgement is pronounced. However, by virtue of $\S 2$ of that Article, the Court may at any time find that the conditions of its competence are not satisfied, however, it is not a question of examining the competence of the national court. On the other hand, Article 267 TFEU provides that the CJEU has jurisdiction to give

${ }^{10}$ Due to Articles 29 and 49 of the Act of 25 July 2002 - Law on the system of administrative courts (Journal of Laws 2021, item 137).

${ }^{11}$ OJ L 265/25, 29.09.2012. 
preliminary rulings. It may be inferred from the second and third sentences of that provision that, where a question concerning the interpretation of the Treaties or the validity and interpretation of acts of the institutions, bodies, offices or agencies of the Union is raised before a national court, that court may or must refer that question to the CJEU if the CJEU's decision is necessary to resolve the case pending before the national court. ${ }^{12}$ The adoption of such legal solutions indicates that the jurisdiction to refer a question for a preliminary ruling is determined at the level of national law, which means that the national court must ensure that its jurisdiction to refer a question is observed.

Such a solution may, in principle, be regarded as correct, provided that the national courts act in accordance with the rules governing the proceedings before them and refer for a preliminary ruling questions relating to the matter under consideration. If this is the case, the CJEU may assess the substance of the question from the perspective of the EU law. On that basis, it may either give or refuse to provide an answer. However, it appears that this is not an optimal situation, since the CJEU does not have a clearly defined way of verifying the jurisdiction of the authority submitting the question. As a consequence of the lack of such legal solutions, a question for a preliminary ruling submitted by an unauthorised entity may be resolved. It comes out that this is the situation in the case of the CJEU judgement of 19 November 2019, when the CJEU answered the question presented by the Supreme Court in its decision of 30 August 2018. ${ }^{13}$

EU law does not define the concept of a preliminary ruling case. Article 267 TFEU only indicates what issues may be the subject of such a question and links them to the need to resolve the case pending before the court. Such an approach to a preliminary ruling question unambiguously links the answer to the case pending before the court, and the national court's inability to pronounce on issues of EU law. There is an extensive body of academic literature on the concept of the question referred for a preliminary ruling (in German: Vorfrage or Zwischenvrage).$^{14}$ On the basis of the findings made therein, it should be assumed that the preliminary question resolved by a preliminary ruling is a question of law, which binds the court in the area of the preliminary question, when deciding the case pending before that court. The concept of the preliminary ruling case as used in academic and judicial research assumes that there is a close connection between the main proceedings and the legal issue which is the subject of the preliminary ruling. The relationship between the principal case

${ }^{12}$ More broadly, see M. Szpunar, Komentarz do art. 267 Traktatu o funkcjonowaniu Unii Europejskiej, [in:] Traktat o funkcjonowaniu Unii Europejskiej, ed. A. Wróbel, vol. 3, Warszawa 2012.

13 III PO 7/18, BOSN.

${ }^{14}$ For example, see J. Rodziewicz, Prejudycjalność w postępowaniu cywilnym, Gdańsk 2000, pp. 7-25; G. Łaszczyca, Zawieszenie ogólnego postępowania administracyjnego, Kraków 2005, pp. 87-121; Z. Czarnik, Podstawy zawieszenia postępowania sądowoadministracyjnego, Przemyśl 2007, p. $233 \mathrm{ff}$. 
and the question for a preliminary ruling is characterised by the fact that the decision in the case for a preliminary ruling becomes the basis for the decision in the principal case. It is only disputed in academic circles whether the preliminary ruling is an element of the legal or factual basis of the principal decision. ${ }^{15}$

With such an understanding of the preliminary ruling case under Polish law, there is no reason why this concept should function in a different sense in connection with the question for a preliminary ruling to be determined by the CJEU, especially since under Article 267 TFEU it is a question of determining the validity and uniform interpretation to the EU law, and thus we are dealing here directly with a legal issue. If this is the nature of the question referred for a preliminary ruling by the CJEU, it follows that there must be a close connection between the principal case against which the question for a preliminary ruling is referred to the CJEU and the decision of the case by the court submitting the question, such that the principal case not only depends on the answer to the question, but also, and above all, falls within the cognition of the court submitting the question. The absence of such a relationship disqualifies the question and renders the answer legally uncertain.

In view of the above, serious doubts must be raised about the jurisdiction of the Supreme Court, which initiated the preliminary ruling procedure with the question contained in the decision of 30 August 2018. It is difficult to look for justification for such an action in this ruling. In the extensive arguments, which are essentially collateral, because they refer to the statutory changes in the system of the Supreme Court and the scope of jurisdiction of the newly created chambers in that court, there are no convincing considerations that would justify the legal legitimacy of a preliminary ruling question to the CJEU. Thus, neither constitutional nor statutory grounds for such action are indicated there. The Supreme Court limits itself to a laconic statement that the appeal against the resolution of the National Council of the Judiciary on retirement pursuant to Article $111 \S 1$ of the Supreme Court Act was directed to the Supreme Court - Labour and Social Insurance Chamber, and until the entry into force of the new Supreme Court Act, this Chamber was competent to hear such cases. It was inferred from this legal situation, which was not in force at the time the question was put to the CJEU, that the Labour and Social Insurance Chamber retained jurisdiction over these cases, since at the time the appeal against the resolution of the National Council of the Judiciary was filed, the Disciplinary Chamber established by the Supreme Court Act did not yet exist. Such considerations are surprising in their inconsistency, to say the least, and certainly cannot constitute a correct basis for establishing the jurisdiction of the

15 See L. Peiper, Komentarz do kodeksu postępowania cywilnego, Kraków 1934, p. 450; J. Rodziewicz, op. cit., p. $32 \mathrm{ff}$. It is rather assumed that this is an element of the factual basis for judgements. 
hitherto existing Labour and Social Insurance Chamber to submit a preliminary ruling question to the CJEU.

First of all, the jurisdiction of any authority, not to mention a court and not even the Supreme Court, cannot be the result of interpretation. It must follow directly from the provisions of the law. Therefore, assuming jurisdiction in the manner presented above, the Supreme Court should indicate the specific provisions determining its jurisdiction to submit a question. It did not do so, because it could not do so, as such norms did not exist at that moment. Nor do they exist in current law, despite the fact that the Supreme Court Act has been subject to numerous amendments since then. Nor can such a legal basis be reconstructed on the basis of the provisions of the Act on the National Council of the Judiciary. In the view of the above, one possible conclusion arises that the preliminary question which found its resolution in the CJEU judgement of 19 November 2019 was referred by the wrong court. As a consequence of this, a doubt arises as to the binding force of this judgement. Such a conclusion is justified in the current legal state.

In the Polish legal system, the acquisition of a retired status occurs as a result of either a judge's transfer to retirement or a judge's retirement. This different statutory presentation of the reasons for acquiring a retirement status forces us to consider the legal consequences of acquiring a retirement status on the basis of specific conditions. The nature and legal character of the status of judge is disputed. Neither the doctrine nor the judicature has reached an unequivocal conclusion in this respect. ${ }^{16}$ The lack of general agreement in this respect is not tantamount to the lack of certain findings as to the two-faceted nature of this relationship and acceptance of views that it consists of public law and employee elements. ${ }^{17}$ In view of the foregoing, a precise grasp of the meaning of the linguistic terms used by the legislature in describing the reason for the judicial retirement status appears to be necessary for a correct definition of retirement status. The constitutional regulation of the retired status cannot be overlooked either.

Article 180 of the Constitution of the Republic of Poland ${ }^{18}$ provides that retirement may result from various actions. It follows from the wording of Article 180 (3) of the Polish Constitution ${ }^{19}$ that a judge may be retired as a result of illness or

${ }^{16}$ For example, see decision of the Supreme Court of 11 January 2016, III SO 3/16, LEX no. 2051075.

17 See Pozycja ustrojowa sędziego, eds. K. Gonera, R. Piotrowski, Warszawa 2015.

${ }_{18}$ Constitution of the Republic of Poland of 2 April 1997 (Journal of Laws 1997, no. 78, item 483, as amended), hereinafter: the Polish Constitution. English translation of the Constitution at: www.sejm.gov.pl/prawo/konst/angielski/kon1.htm [access: 10.12.2021].

19 More broadly, see Z. Czarnik, Zagadnienia proceduralne sędziowskiego stanu spoczynku, Warszawa 2020, pp. 32-36; M.J. Zieliński, Obniżenie ustawowej granicy przechodzenia $w$ stan spoczynku przez sędziów sądów powszechnych, administracyjnych i Sądu Najwyższego w świetle przepisów dyrektyw nr 2000/78/WE oraz 2006/54/WE, "Przegląd Sądowy" 2018, no. 10, pp. 5-25; 
loss of strength preventing him or her from holding office. Therefore, one of the ways leading to retirement is the transfer into retirement when the loss of strength or illness has occurred. The second situation related to the retirement of a judge is set out in Article 180 (5) of the Polish Constitution. Here the constitutional legislator provides that in the event of a change in the system of courts or in the boundaries of court districts, a judge may be transferred to another court or retired with full emoluments. It should be noted that both editorial units of the analysed provision consistently use the term "transfer" to a retired status. Since transfer in such cases is always associated with an element of compulsion, the Polish Constitution requires that actions in this mode be subject to the right of appeal to court.

In turn, Article 180 (4) of the Polish Constitution provides for the attainment of retirement as a result of age. According to this provision, the law determines the age limit upon reaching which a judge retires. Thus, on account of age, a judge is not transferred to the retirement status, but a judge undergoes retirement. The linguistic distinction at the constitutional level between "transferring" and "undergoing" must lead to a distinction between the grounds and the ways of acquiring retirement. Thus, the correct definition of the mode of reaching retirement is important for the correct characterisation of the mechanisms governing the acquisition of retirement and, ultimately, the assignment of the appropriate legal means to guarantee the protection of the acquisition of the retirement status.

There is no doubt in the doctrine ${ }^{20}$ and judicature ${ }^{21}$ that constitutional terms have their own meaning, which cannot be determined on the basis of the content of terms found in ordinary legislation. This view has been consistently accepted, although it has been pointed out that the autonomy of constitutional notions may not lead to a complete disregard or rejection of the understanding of terms found in ordinary legislation. ${ }^{22}$ Emphasising the autonomous character of constitutional

\footnotetext{
A.M. Światkowski, Prawny spór o zgodność z Konstytucją RP regulacji i ich następstw osiagnięcia „,wieku emerytalnego" przez sędziów Sądu Najwyższego, "Palestra” 2018, n. 10, pp. 5-12.

${ }^{20}$ See K. Zaradkiewicz, Instytucjonalizacja wolności majątkowej. Koncepcja prawa podstawowego własności i jej urzeczywistnienie w prawie prywatnym, Warszawa 2013, p. 171 ff.; idem, Własność i jej ochrona jako wzorzec kontroli konstytucyjności. Wybrane problemy, "Kwartalnik Prawa Prywatnego" 2009, no. 3, p. 890; T. Dybowski, Konstytucyjne i cywilnoprawne pojęcie własności, [in:] Sadownictwo a obowiazujacy system prawny. Materiaty z konferencji zorganizowanej przez SN w dniach 13-14 lutego 1992 r., Warszawa 1992, pp. 190-191; L. Morawski, Wyktadnia w orzecznictwie sądów, Torun 2002, p. 209; S. Jarosz-Żukowska, Konstytucyjna zasada ochrony własności, Kraków 2003, pp. 15-31; M. Gutowski, P. Kardas, Wyktadnia i stosowanie prawa w procesie opartym na konstytucji, Warszawa 2017, pp. 528-530.

${ }_{21}$ See judgement of the Constitutional Tribunal of 7 March 1995, W 9/94, OTK 1995, no. 1, item 20; judgement of the Constitutional Tribunal of 21 March 2000, K 14/99, OTK 2000, no. 2, item 61; judgement of the Constitutional Tribunal of 14 March 2000, P 5/99, OTK 2000, no. 2, item 60.

${ }^{22}$ Such an issue appears in the context of deliberations on the direct derogatory effect of a constitutional norm. See M. Gutowski, P. Kardas, op. cit., pp. 583-616; judgement of the Constitutional
} 
notions one should always refer to the structure of the legal language shaped in the pre-constitutional practice of law application. Within the framework of the presented comments, the interpretation of the content of Article 180 (3) to (5) of the Polish Constitution does not seem to pose any difficulties, particularly since the constitutional and ordinary legislatures use the same terminology to define the same phenomena related to the acquisition of judicial retirement. For this reason, the autonomy of constitutional terms, important as it is as a theoretical issue, does not pose an interpretative problem with respect to retirement status, although the jurisprudence pays little attention ${ }^{23}$ to it and even fails to note the linguistic distinctions made under the Constitution. The finding of such a fact should be a cause for concern, since the application of the law must first and foremost be connected with determining the content of the norms applied, and this can only be done on the basis of language. ${ }^{24}$

It should be stressed once again that the constitutional regulation of retirement status coincides with the statutory one when it comes to the terminology describing the transformation of an active judgeship into a retirement status. Paragraphs 3 and 5 of Article 180 of the Polish Constitution indicate the transfer of a judge to a retired status, while paragraph 3 of this provision regulates the transition to a retired status. The statutory solutions correspond to this approach. Each of the laws regulating retirement of judges distinguishes between transfer and retirement. The acts in this respect consistently differentiate between the criteria for retirement and also regulate the procedure leading to its determination in a different manner. From this perspective, the regulation of the Supreme Court Act must be stated to be precise and consistent, which must be viewed positively, since such a state constitutes a guarantee of judicial independence. What may cause concern, however, is the practice of treating such linguistic obviousness in a rather relaxed manner, assuming that each basis for retirement of judges is subject to the same legal procedure. Hence, there is the problem of the effectiveness of the preliminary ruling question to the CJEU posed by the Supreme Court of 30 August 2018.

It should be noted that even the Act 12 May 2011 on the National Council of the Judiciary ${ }^{25}$ does not contain a regulation which could provide a basis for ascribing jurisdiction to the Supreme Court in matters of retirement. It follows from Article 3 (2) of the National Council of the Judiciary Act, i.e. the provision defining the tasks of the Council, that with respect to matters concerning judges

Tribunal of 6 October 1998, K 36/97, OTK 1998, no. 5, item 65; judgement of the Constitutional Tribunal of 8 March 2000, Pp 1/99, OTK 2000, no. 2, item 98; resolution of the Supreme Administrative Court of 12 October 1998, OPS 5/98, ONSA 1999, no. 1, item 1.

${ }^{23}$ See decision of the Supreme Court of 30 August 2018, III PO 7/18, BOSN.

${ }^{24}$ See Ch. Perelman, Logika prawnicza. Nowa retoryka, Warszawa 1980, pp. 164-165.

25 Journal of Laws 2019, item 84, hereinafter: National Council of the Judiciary Act. 
the Council has two powers, obviously apart from its competence in nomination proceedings. These include motions to transfer a judge to a retired status and motions by retired judges to return to judicial office. These two powers encapsulate the Council's authority in relation to judges. The Council's authority to act in other matters, namely retirement, cannot be derived from those provisions. Irrespective of that, any acts undertaken by that body may be appealed against on the principles arising from the provisions of law. Thus, they may be the subject of an appeal to the Supreme Court in strictly indicated situations. In the remaining scope, such a way does not exist, which does not mean that they are beyond control. It seems that they are subject to such control, however, in court-administrative proceedings, and thus may be subject to a complaint to that court. ${ }^{26}$

First and foremost, the jurisdiction of the National Council of the Judiciary to act in the matter of retired judges cannot be derived from the provisions of Chapter 3 of the National Council of the Judiciary Act, which regulates proceedings before the Council. The fact that it follows from Article 29 (1) of the National Council of the Judiciary Act that in individual cases the person whose rights or obligations are to be affected by the resolution of the Council is a party to the proceedings cannot be inferred that the Council may act in every individual case. ${ }^{27}$ First of all, this provision is a procedural provision, and thus it does not constitute subjective rights, and moreover, it can only be interpreted in such a way that if the matter falls within the Council's jurisdiction and is an individual case, then the person whose case is being handled by the Council is a party to the proceedings. ${ }^{28}$ For these reasons the view that the Council is the body authorised to pronounce on retirement is all the more unfounded, since it has such authorisation only when a judge is transferred to this status. The practice shaped against this background, which is inherently flawed, cannot be the basis for submitting a preliminary ruling to the CJEU, as argued by the Supreme Court in its decision of 30 August 2018, and as a result for the CJEU ${ }^{29}$ to issue a judgement and the Supreme Court to adopt a resolution. ${ }^{30}$

The consequence of the presented position cannot be the assertion that the retirement of a judge is excluded from control. On the contrary, the view that such control of retirement does not lie with the Supreme Court seems justified. An analysis of the existing legal state justifies the view that this type of case is subject

26 See Z. Czarnik, Zagadnienia proceduralne ..., pp. 96-112; S. Biernat, Czy i jak kontrolować procedurę powołania sędziów do Sądu Najwyższego, "Europejski Przegląd Sądowy" 2021, no. 3, p. $1 \mathrm{ff}$.

${ }^{27}$ See inaccurately M. Niezgódka-Medek, R. Pęk, Krajowa Rada Sądownictwa. Komentarz, LEX/el. 2013, commentary to Article 29.

${ }^{28}$ See Z. Czarnik, Zagadnienia proceduralne..., p. 110.

29 Judgement of the CJEU of 19 November 2019, C-585/19, C-624/18 and C-625/18, ECLI:EU:C:2019:982.

${ }^{30}$ Resolution of the Supreme Court of 23 January 2020, BSA I 4110-1/20, LEX no. 2770251. 
to review by the administrative courts. The following circumstances support such a thesis. Since its enactment, Article 44 of the National Council of the Judiciary Act has provided that a participant in proceedings may appeal to the Supreme Court on the grounds that a resolution is contrary to the law, unless the provisions provide otherwise. It is apparent from the wording of the chapter in which this provision is found that the resolutions subject to appeal relate to applications for judicial office (Article 35), retirement of a judge (Article 38) and return to active status (Article 39). ${ }^{31}$

Thus, it is only in this catalogue of matters that the Council's authority to act, i.e. adopt a resolution, is confined and only such resolution may be appealed against by a participant to the Supreme Court. The provisions under analysis were subject to numerous amendments in connection with the dispute over the judiciary reform, but the appeal mechanism adopted therein was not subject to change, although at one point the legislator introduced a solution whereby in individual cases concerning the appointment to the office of a judge of the Supreme Court, an appeal was to be lodged with the Supreme Administrative Court, and not with the Supreme Court as in the case of other judges. ${ }^{32}$ The reasons for this change were not clearly articulated, but from a systemic perspective it was a solution that seemed more appropriate than leaving the path before the Supreme Court. It was more appropriate because, in the case of an appointment, the essence of the matter concerns a public-law issue, so it naturally falls more within the broader meaning of public administration in the constitutional sense, especially as there is no dispute in the case law that the National Council of the Judiciary should be treated as an authority within the meaning of Article 184 of the Polish Constitution. ${ }^{33}$

\section{CONCLUSIONS FROM THE ANALYSIS - JURISDICTION TO RULE ON THE RETIREMENT STATUS OF A JUDGE OF THE SUPREME COURT}

Summing up, it should be stated that under the current law the choice of the appropriate way to protect a judge in connection with his/her retirement is an ambiguous issue. It appears, however, that the state of the law permits acceptance, as justified, of the position that with respect to the retired status of a judge, the

${ }^{31}$ I have already presented this issue extensively earlier and in this respect I rely on the view. See Z. Czarnik, Legal nature of an official act of the President of the Republic of Poland pronouncing retirement of the Supreme Court judge, "Ius Novum" 2020, no. 2, pp. 120-134.

32 Article 44 (1a) of the National Council of the Judiciary Act until 1 April 2019 in conjunction with the judgement of the Constitutional Tribunal of 25 March 2019, K 12/18, Journal of Laws 2019, item 609.

33 Judgement of the Constitutional Tribunal of 29 November 2007, SK 43/06, OTK 2007, no. 10 , item 130. 
appropriate and legally justified route is the civil procedure, which functions as a uniform solution for all judges, irrespective of the fact that certain solutions with respect to judges of the Supreme Court and judges of common courts may differ in detail. The provisions of the Supreme Court Act, but also of the National Council of the Judiciary Act, speak directly in favour of the jurisdiction of the Supreme Court in these matters. "Undergoing retirement" is not a "transfer" and thus the procedure specific to transfer cannot be applied to it. The law does not contain specific solutions in this respect, leaving this issue to interpretation, and this allows us to claim that the path of judicial-administrative control is open for the transition.

This type of review meets the constitutional requirement of guaranteeing the right to a court, and since the transfer is the result of the occurrence of conditions specified by law, the scope of such review is limited to examining the legality of the act confirming the retirement. This means that the administrative court's examination of only the legality of the act meets the constitutional standard for the protection of the judge. The result of such a position must be the conclusion that the Supreme Court had no competence to formulate the question to the CJEU in its decision of 30 August 2018, and the judgement itself, which is the answer to it, is issued in a case which was not materially the main case decided by the Supreme Court. For these reasons, it should be considered that both the Supreme Court in this case and the CJEU ruled beyond the competences granted by law.

In a different formal aspect, the judgement of the CJEU of 2 March 2021 should be assessed. The necessity to ask questions in this respect was derived from the episodic regulation of the appeal route against the resolution of the National Council of the Judiciary presenting candidates for the position of judge in the Supreme Court and the assumption in this regulation that the route before the Supreme Administrative Court is appropriate for these candidates for judges. The introduction of such a solution into the Act was motivated by extra-legal reasons, but the procedural effect seemed correct. Firstly, to a certain extent it introduced an element of independence into the assessment of such resolutions, because the appeal was examined by a body other than that to which the candidates had applied, thus confirming the nemo iudex in causa sua rule. At the same time, this solution was not entirely consistent, as the provisions on the Supreme Court applied to Supreme Administrative Court judges accordingly. Secondly, it indicated a more appropriate way to control such acts due to the public-law nature of the appointment.

Such a view seems appropriate in spite of what the constitutionality of the appeal route adopted in Article 44 (1a) of the National Council of the Judiciary Act was found by the Constitutional Tribunal. ${ }^{34}$ In this respect, the Constitutional Tribunal stated that there are no legal premises supporting the jurisdiction of the Supreme Administrative Court as a court authorised to examine the appeal in the

\footnotetext{
${ }^{34}$ Judgement of the Constitutional Tribunal of 25 March 2019, K 12/18, OTK 2019, item 17.
} 
matter of appointment to a judicial post in the Supreme Court. At the same time, the Constitutional Tribunal confirmed that in such proceedings, the court reviewing the National Council of the Judiciary resolution in this matter may not make a substantive assessment of the conditions fulfilled by a candidate for a judge, but should only comment on the legality of the procedure itself, in which such assessment is made. With this position, it referred to an earlier judgement of the Constitutional Tribunal establishing the scope of the appealability of a resolution of the National Council of the Judiciary indicating a candidate for a judicial post. Thus, in its judgement of 25 March 2019, the Constitutional Tribunal, ruling in favour of an appeal route before the Supreme Court, contradicted the assumption made earlier in the justification of the judgement ${ }^{35}$ which, in the opinion of the Constitutional Tribunal, should support the examination of the case by the Supreme Court.

Since the subject of such an appeal is only the legality of the procedure in which the opinion on the candidate was formulated, it does not in any way concern the substantive examination of the case, and this context would determine - in the opinion of the Constitutional Tribunal - the jurisdiction of the Supreme Court. It seems that the opposite is true. The legality of the authorities' actions is the sphere of judicial and administrative control. Undoubtedly, the Constitutional Tribunal is correct when it asserts that there are no systemic reasons for the same cases to be within the jurisdiction of two different courts. It should be assumed that from a logical point of view, the opposite conclusion is correct. This does not change the normative state of affairs, because the legislature has determined that appeals against resolutions of the National Council of the Judiciary assessing candidates for judges are within the jurisdiction of the Supreme Court. Such a solution is not juridically sound, but it is permissible under the constitutional provisions.

After all, Article 183 (2) of the Polish Constitution provides that the Supreme Court performs the activities set forth in the Constitution and statutes, while Article 184 of the Polish Constitution implies that administrative courts and the Supreme Administrative Court exercise control over public administration within the scope specified by law. Thus, the law may make different choices as to the way of appealing against resolutions of the National Council of the Judiciary. It should be stressed, however, that the freedom of legislative choice in this matter is not complete, and the legislator should take into account the nature of the cases, while dividing them between common and administrative courts. In the analysed case this rule was not realised, which is probably not a correct systemic approach. However, it is a solution that meets the standard of constitutionality in the sense that it provides the person participating in the competition with the right to a court. Although it is limited only to the formal context, even in this scope it meets the constitutional requirement of Article 45 of the Polish Constitution. The same scope

35 Judgement of the Constitutional Tribunal of 27 May 2008, SK 57/06, OTK 2008, item 63. 
of this right is exercised by the Supreme Administrative Court, so it is difficult to find any superfluity in the position of the Constitutional Tribunal that would speak in favour of adjudication by the Supreme Administrative Court.

Therefore, the preliminary ruling by the Supreme Administrative Court to the CJEU in these cases had a clear statutory basis, regardless of the assessment of the constitutionality of the adopted solution. This means that at the moment of putting forward the questions, there were no doubts as to the legal basis for such action. The Supreme Administrative Court did not presume its jurisdiction in this respect. It was implementing the provisions of the Act. Another issue is the content of the answer given, especially the potential necessity to apply EU law in a situation where it would be in contradiction with the Polish Constitution. In this respect, one may have serious doubts whether such an action is permissible on the grounds of the extensive jurisprudence ${ }^{36}$ of the Constitutional Tribunal and the views of the judicature. However, from the formal point of view, the response of the CJEU is directly and closely connected with the main case pending before the Supreme Administrative Court. Therefore, it should be recognised that in this case we are dealing with a correctly posed preliminary ruling question, and the consequences of the answer to it must be taken into account in the examined cases according to the criteria set out by the Constitutional Tribunal.

Of course, it is possible to take into account the position of the CJEU only to the extent permitted by the constitutional framework, bearing in mind that, in many areas, there is an identity of standards between the Polish Constitution and EU law, so that in these areas there is never a collision of legal norms. ${ }^{37}$ Nevertheless, it should be consistently held that EU law is directly applicable only to the extent permitted by the Polish constitutional order. EU law, and especially the jurisprudence of the CJEU, which is a specific source of law, may not invalidate constitutional regulations. This follows directly from the views presented by the Constitutional Tribunal, ${ }^{38}$ which does not apply the principle of precedence directly to the Constitution. Such a phenomenon is not only a Polish characteristic. In theses 16-19 of the French Constitutional Council of 20 December 2007, it was clearly articulated that the ratification of the Lisbon Treaty is possible only with a constitutional amendment, as only in this legal solution can no treaty conditions infringing

${ }^{36}$ See J. Barcz, Glosa do wyroku TK z 11.05.2004, K 18/04 (zgodność Traktatu akcesyjnego $z$ Konstytucja RP, K 18/04), "Kwartalnik Prawa Prywatnego" 2005, no. 4, p. 169.

37 More broadly, see N. Półtorak, Imagine - rola prawa i prawników w integracji europejskiej, "Europejski Przegląd Sądowy" 2021, no. 3, pp. 4-7; K. Lenaerts, Żadne państwo członkowskie nie jest równiejsze od innych-zasada pierwszeństwa prawa Unii Europejskiej i zasada równości państw wobec traktatów, "Europejski Przegląd Sądowy" 2021, no. 1, pp. 4-7.

38 Judgement of the Constitutional Tribunal of 11 May 2005, K 18/04, OTK 2005, no. 5, item 49. Especially, see judgement of the Constitutional Tribunal of 24 November 2010, K 32/09, OTK 2010, no. 9 , item 108 . 
the exercise of national sovereignty be imposed. The Federal Constitutional Court of Germany ${ }^{39}$ has expressed itself in a similar direction.

Thus, under Polish law, the principle of the primacy (supremacy) of EU law over domestic law should be adopted, but in a form that does not violate the constitutional order, i.e. in so far as the answer to the question for a preliminary ruling does not invalidate the constitutional provision. The need to observe such a rule should be the starting point for the rulings of the CJEU when answering the questions posed. Such a presumption allows the law to be harmonised at national level, either through interpretation or sometimes through constitutional amendments. On the other hand, it protects internal legal orders from unauthorised shaping of their foundations by the CJEU, which, as an EU court, should not have any direct influence on constitutional legislation, especially because the EU constitution, which provided for such a solution, has not been adopted. The rejection of such a mechanism cannot result in the admissibility of its introduction by way of accomplished facts.

In view of the above, it should be assumed that the judgement of the CJEU of 2 March 2021 on the formal level meets all the conditions set out by the provisions of EU law. It provides an answer to the question posed by the competent court at the moment of posing the question and is connected to the case pending before this court. In this way, it differs from the judgement of the CJEU of 19 November 2019 , as that one resolved a case presented as a question by a court with no jurisdiction. However, in terms of its merits, it is acceptable only if a binding assumption is made that the demonstrated contradiction of Article 44 (1) and (1a) of the National Council of the Judiciary Act with constitutional provisions, as the basis for assessing the appeal procedure to the Supreme Administrative Court, will be understood only as the necessity to refer this legal solution to the principles set out in the Constitution of the Republic of Poland and not as a requirement to disregard them as contrary to EU law.

\section{REFERENCES}

\section{Literature}

Barcz J., Glosa do wyroku TK z 11.05.2004, K 18/04 (zgodność Traktatu akcesyjnego z Konstytucja $R P, K$ 18/04), "Kwartalnik Prawa Prywatnego" 2005, no. 4.

Biernat S., Czy i jak kontrolować procedurę powołania sędziów do Sądu Najwyższego, "Europejski Przegląd Sądowy" 2021, no. 3.

${ }^{39}$ See theses to the judgement of 30 June 2009 and the judgement of 6 July 2010 presented in the justification of the judgement of the Constitutional Tribunal of 24 November 2010, K 32/09, OTK 2010, no. 9, item 108. 
The Legitimacy of Preliminary Questions to the Court of Justice of the European Union... 167

Czarnik Z., Legal nature of an official act of the President of the Republic of Poland pronouncing retirement of the Supreme Court judge, "Ius Novum" 2020, no. 2.

Czarnik Z., Podstawy zawieszenia postępowania sądowoadministracyjnego, Przemyśl 2007.

Czarnik Z., Zagadnienia proceduralne sędziowskiego stanu spoczynku, Warszawa 2020.

Dybowski T., Konstytucyjne i cywilnoprawne pojęcie własności, [in:] Sąownictwo a obowiąujący system prawny. Materiały z konferencji zorganizowanej przez SN w dniach 13-14 lutego 1992 r., Warszawa 1992.

Gutowski M., Kardas P., Wyktadnia i stosowanie prawa w procesie opartym na konstytucji, Warszawa 2017.

Jarosz-Żukowska S., Konstytucyjna zasada ochrony własności, Kraków 2003.

Lenaerts K., Żadne państwo członkowskie nie jest równiejsze od innych - zasada pierwszeństwa prawa Unii Europejskiej i zasada równości państw wobec traktatów, "Europejski Przegląd Sądowy" 2021, no. 1.

Łaszczyca G., Zawieszenie ogólnego postępowania administracyjnego, Kraków 2005.

Morawski L., Wyktadnia w orzecznictwie sądów, Torun 2002.

Niezgódka-Medek M., Pęk R., Krajowa Rada Sądownictwa. Komentarz, LEX/el. 2013.

Peiper L., Komentarz do kodeksu postępowania cywilnego, Kraków 1934.

Perelman Ch., Logika prawnicza. Nowa retoryka, Warszawa 1980.

Pozycja ustrojowa sędziego, eds. K. Gonera, R. Piotrowski, Warszawa 2015.

Półtorak N., Imagine - rola prawa i prawników w integracji europejskiej, "Europejski Przegląd Sądowy" 2021, no. 3.

Rodziewicz J., Prejudycjalność w postępowaniu cywilnym, Gdańsk 2000.

Sikora A., Praktyka Trybunatu Sprawiedliwości w postępowaniach na podstawie art. 267 TFUE w'świetle orzecznictwa i ostatniej reformy procedury, "Europejski Przegląd Sądowy" 2014, no. 11.

Stelmach J., Brożek B., Metody prawnicze, Kraków 2004.

Szpunar M., Komentarz do art. 267 Traktatu o funkcjonowaniu Unii Europejskiej, [in:] Traktat o funkcjonowaniu Unii Europejskiej, ed. A. Wróbel, vol. 3, Warszawa 2012.

Światkowski A.M., Prawny spór o zgodność z Konstytucją RP regulacji i ich następstw osiagnięcia „,wieku emerytalnego" przez sędziów Sądu Najwyższego, "Palestra” 2018, no. 10.

Zaradkiewicz K., Instytucjonalizacja wolności majątkowej. Koncepcja prawa podstawowego własności i jej urzeczywistnienie w prawie prywatnym, Warszawa 2013.

Zaradkiewicz K., Własność i jej ochrona jako wzorzec kontroli konstytucyjności. Wybrane problemy, "Kwartalnik Prawa Prywatnego" 2009, no. 3.

Zieliński M.J., Obniżenie ustawowej granicy przechodzenia w stan spoczynku przez sędziów sądów powszechnych, administracyjnych i Sadu Najwyższego w świetle przepisów dyrektyw nr 2000/78/ WE oraz 2006/54/WE, "Przegląd Sądowy” 2018, no. 10.

\section{Legal acts}

Act of 25 July 2002 - Law on the system of administrative courts (Journal of Laws 2021, item 137).

Act of 12 May 2011 on the National Council of the Judiciary (Journal of Laws 2019, item 84).

Act of 8 December 2017 on the Supreme Court (Journal of Laws 2018, item 5).

Constitution of the Republic of Poland of 2 April 1997 (Journal of Laws 1997, no. 78, item 483, as amended).

Rules of Procedure of the Court of Justice of 25 September 2012 (OJ L 265/25, 29.09.2012).

Treaty on the Functioning of the European Union (Journal of Laws 2004, no. 90, item 864/2). 


\section{Case law}

Decision of the Supreme Court of 11 January 2016, III SO 3/16, LEX no. 2051075.

Decision of the Supreme Court of 30 August 2018, III PO 7/18, BOSN.

Judgement of the CJEU of 19 November 2019, C-585/19, C-624/18 and C-625/18, ECLI:EU:C:2019:982.

Judgement of the CJEU of 2 March 2021, C-842/18.

Judgement of the Constitutional Tribunal of 7 March 1995, W 9/94, OTK 1995, no. 1, item 20.

Judgement of the Constitutional Tribunal of 6 October 1998, K 36/97, OTK 1998, no. 5, item 65.

Judgement of the Constitutional Tribunal of 8 March 2000, Pp 1/99, OTK 2000, no. 2, item 98.

Judgement of the Constitutional Tribunal of 14 March 2000, P 5/99, OTK 2000, no. 2, item 60.

Judgement of the Constitutional Tribunal of 21 March 2000, K 14/99, OTK 2000, no. 2, item 61.

Judgement of the Constitutional Tribunal of 11 May 2005, K 18/04, OTK 2005, no. 5, item 49.

Judgement of the Constitutional Tribunal of 29 November 2007, SK 43/06, OTK 2007, no. 10, item 130.

Judgement of the Constitutional Tribunal of 27 May 2008, SK 57/06, OTK 2008, item 63.

Judgement of the Constitutional Tribunal of 24 November 2010, K 32/09, OTK 2010, no. 9, item 108. Judgement of the Constitutional Tribunal of 25 March 2019, K 12/18, Journal of Laws 2019, item 609. Judgement of the Constitutional Tribunal of 25 March 2019, K 12/18, OTK 2019, item 17. Judgement of the Supreme Court of 5 December 2019, III PO 7/18, BOSN.

Resolution of the Supreme Administrative Court of 12 October 1998, OPS 5/98, ONSA 1999, no. 1, item 1.

Resolution of the Supreme Court of 23 January 2020, BSA I 4110-1/20, LEX no. 2770251.

\section{ABSTRAKT}

Przedstawiona analiza odnosi się do wpływu orzecznictwa Trybunału Sprawiedliwości Unii Europejskiej (TSUE) na kształtowanie w Polsce sytuacji prawnej sędziów Sądu Najwyższego (SN) i Naczelnego Sądu Administracyjnego (NSA). Głównym założeniem przedstawionych rozważań jest stwierdzenie, że TSUE w ramach udzielanych odpowiedzi na pytania prejudycjalne, kierowane do niego przez polskie sądy, rozpoznające sprawy związane z powołaniami na stanowisko sędziowskie oraz z przejściem w stan spoczynku, wzmacnia niezależność sądów i niezawisłość sędziowską, przyjmując, że są to elementy ustrojowe funkcjonującego wymiaru sprawiedliwości podlegające prawu Unii Europejskiej. Z tego powodu TSUE uznaje się za właściwy do kształtowania tych wartości ustrojowych na gruncie prawa polskiego. Jednocześnie organ ten nie zauważa problemu właściwości polskich sądów występujących z pytaniami prawnymi, co staje się ważnym zagadnieniem teoretycznym i praktycznym, gdyż może rzutować na legalność i skuteczność orzeczeń zapadających na podstawie udzielonych przez TSUE odpowiedzi. Szczegółowe rozważania koncentrują się na dwóch rodzajach orzeczeń TSUE, które zapadły w związku z sędziowskim stanem spoczynku, na skutek wystąpienia do TSUE z pytaniami przez SN i NSA. Przedmiot pytań odnosił się do zgodności z prawem unijnym zakresu ochrony prawnej przyznanej w prawie polskim sędziemu od uchwał podejmowanych w tych sprawach przez Krajową Radę Sądownictwa. Konkluzją przedstawionych rozważań jest stwierdzenie, że w przypadku wyroku TSUE wydanego na skutek pytania SN doszło do naruszenia właściwości organu występującego z pytaniem, a to powinno mieć konsekwencje dla zakresu związania sądu orzekającego odpowiedzią udzieloną przez TSUE.

Słowa kluczowe: pytanie prejudycjalne; Trybunał Sprawiedliwości Unii Europejskiej; Krajowa Rada Sądownictwa; stan spoczynku sędziego; prawo polskie 